\title{
PIMPINAN LEMBAGA PERGURUAN TINGGI KEAGAMAAN ISLAM (PTKI) VISIONER DAN ORIENTASI TOTAL QUALITY SEBAGAI LOKOMOTIF KESIAPAN PTKI DALAM MENYONGSONG MASYARAKAT EKONOMI ASEAN (MEA)
}

\author{
Aguswan Khotibul Umam \\ Dosen Pascasarjana STAIN Jurai Siwo Metro
}

\begin{abstract}
These days, the universities are required to be prepare of quality assurance in becoming ASEAN Economic Society. Therefore, the visionary leadership sense inside PTKI like structure, focus, recognize legality, communication, dinamic style, and responsive are needed to create the qualified PTKI. At least the qualified PTKI should have 8 factors such as scores and assignment, organization structure, communication, decision-making by agreement, and dinamic curriculum planning. Visionary leadership is vision based, which have the ability to face the reality and confidence in making people to be sure that the visions will be realize. The ability that should have by visionary leadership are: (a) capable in making good connection with staff and employment (in organization) who need guidance, support, and motivation; (b) capable in employing the external area maximally and have good relation with the outer which make the organization success; (c) capable in creating and influencing whole operation aspect of organization including the visions achievement, the quality of control system, the organization structure, and the information system; (d) capable and smart in dealing the future.
\end{abstract}

Key words: Islamic Collage, ASEAN Economic Society, Leader, Visoner, Organization

\begin{abstract}
Abstrak
Perguruan Tinggi dewasa ini dituntut untuk selalu siap mengedepankan quality assurance dalam menyongsong Masyarakat Ekonomi ASEAN. Untuk itu diperlukan pola kepemimpinan yang visioner dalam tubuh PTKI untuk mewujudkan budaya mutu PTKI yaitu: struktur, fokus, atau legalitasnya diakui, komunikasi, gaya (style) yang dinamis, dan responsif. Setidaknya terdapat 8 faktor yang mempengaruhi prosesi pengembangan budaya mutu di PT yaitu: Nilai-nilai dan tugas, Struktur organisasi, Komunikasi, Pengambilan keputusan yang didasari mupakat, Perencanaan kurikulum yang dinamis. Kepemimpinan visioner merupakan kepemimpinan yang berdasarkan visi, yaitu kemampuan untuk melihat realitas, memberi pemimpin keyakinan diri yang dibutuhkan untuk mencurahkan perhatiannya secara terus-menerus untuk meyakinkan orang lain bahwa visi tersebut akan menjadi kenyataan. Kemampuan yang harus dimiliki oleh pemimpin visioner adalah: (a) mampu berhubungan secara terampil dengan para staf dan karyawan (dalam organisasi) yang mengharapkan bimbingan, dorongan dan motivasi; b) mampu memanfaatkan lingkungan eksternal secara maksimal dan berhubungan secara terampil dengan pihak-pihak di luar organisasi yang mempengaruhi keberhasilan organisasi; c) mampu membentuk dan mempengaruhi semua aspek operasi organisasi termasuk pencapaian visi, kualitas sistem pengendalian, struktur organisasi, dan sistem informasi; d) mampu dan cerdik dalam menyiasati masa depan.
\end{abstract}

Kata Kunci: Perguruan Tinggi Keagamaan Islam (PTKI), Masyarakat Ekonomi Asean (MEA), Pemimpin, Visioner, Organisasi. 


\section{Pendahuluan}

Upaya untuk menciptakan manusia Indonesia yang sempurna, baik pada dimensi spiritual, intelektualitas, maupun tanggung jawab sosialnya adalah tujuan pendidikan nasional Indonesia. ${ }^{1}$ Ketercapaian tujuan ini tergantung pada perencanaan sistem pendidikan nasional yang baik dan implementasi yang nyata dan penuh tanggung jawab oleh seluruh pihak yang berkompeten di Indonesia. Namun, perlu disadari bahwa dalam proses pencapaian cita-cita pendidikan nasional terdapat berbagai hambatan, yaitu "terdapat tiga dinamika perubahan yang berimplikasi pada kehidupan manusia, yakni perubahan globalisasi, demokratisasi, dan kemajuan teknologi informasi."2

Kemampuan masing-masing lembaga pendidikan dalam mengikuti serta filterisasi ketiga perubahan tersebut secara dinamis, adalah menjadi penentu sukses tidaknya pencapaian cita-cita pendidikan nasional melalui masing-masing lembaga pendidikan secara riil, termasuk pada Perguruan Tinggi Keagamaan Islam (PTKI).

Di era globalisasi dan persaingan bebas dibutuhkannya kemampuankemampuan sumber daya manusia yang mumpuni, yaitu "manusia yang kreatif, inovatif, dinamis, terbuka, bermoral baik, mandiri atau penuh percaya diri, menghargai waktu, mampu berkomunikasi dan memanfaatkan peluang serta menjadikan orang lain sebagai mitra." 3 Kriteria-kriteria SDM tersebut menjadi penentu eksistensi lembaga-lembaga pendidikan, spesifikasinya pada PTKI di Indonesia agar tetap eksis secara fungsional di tengah-tengah kehidupan global serta persaingan bebas serta dalam menyongsong masyarakat ekonomi ASEAN.

Tenaga-tenaga SDM di PTKI harus mampu mengatasi kelemahan umat Islam di Indonesia serta pada setiap civitas akedimika PTKI harus dapat beraktualisasi sesuai dengan kualitas dan profesionalitas SDM yang dimiliki. SDM PTKI juga dituntut untuk eksis dan survive, yaitu mampu merubah berbagai tantangan menjadi peluang, dan merubah peluang tersebut menjadi hal yang produktif dan tidak sebaliknya yaitu kontra produktif.

PTKI harus secara mandiri dan memiliki iktikad yang mulia untuk menciptakan SDM yang memadai baik kapasitas sebagai individu, kelompok maupun sebagai bangsa agar mampu secara eksis bekerjasama dan kompetitif dalam kancah perkembangan zaman sehingga transformasi nilai-nilai humanis secara kebangsaan dan ukhuwah Islamiyah dapat berjalan lancar.

1Yaitu pada Undang-Undang Sisdiknas No. 20. Tahun 2003, pasal 3.

2Tilaar, Perubahan Sosial dan Pendidikan: Pengantar Pedagogik untuk Indonesia, (Jakarta: PT Grasindo, 2002) hal. 472.

${ }^{3}$ Abudin Nata, Manajemen Pendidikan: Mengatasi Kelemahan Pendidikan Islam di Indonesia, (Jakarta: Prenada Media, 2003), hal, 170.

RI'AYAH, Vol. 01, No. 01 Januari-Juni 2016 
Pengembangan nilai-nilai keislaman harus menjadi prioritas dan terinternalisasi pada semua komponen penyelenggaraan PTKI di Indonesia, dan menjadikan nilai-nilai ke-Islaman sebagai prioritas utama bagi wadah pembinaan generasi Islam yang berkualitas dan memegang teguh prinsip-prinsip keIslaman dalam konteks kehidupan nyata. "Pendidikan telah dijadikan prioritas utama dan pertama oleh banyak negara sebagai fondasi membangun masyarakat yang lebih demokratis, terbuka bagi perubahan-perubahan global dan menghadapi masyarakat global". ${ }^{4}$

Melalui PTKI, para pendidik Islam dapat menyiapkan generasi Islam untuk memenuhi kualifikasi sebagai "anak didik yang tidak hanya mampu mengembangkan kreatifitas intelektual dan imajinasi secara mandiri, tetapi juga memiliki ketahanan mental spiritual serta mampu berdaptasi dan merespon problematika yang dihadapinya sesuai kerangka dasar ajaran Islam". ${ }^{5}$ Dalam konteks ini, PTKI memiliki peluang yang besar dalam mewujudkan tujuan pendidikan nasional serta menyiapkan SDM bangsa yang berkualitas.

Terkait dengan kesiapan PTKI dalam menyongsong MEA, berikut deskripsi peran strategis PT yang diberikan oleh Prof. Dr. Susilo Bambang Yudhono, bahwa PT bisa masuk ke segala lini sesuai relevansi keilmuannya. Bidang-bidang yang memerlukan kontribusi dari PT serta lembaga pendidikan, kajian dan penelitian, agar Indonesia berada pada posisi yang unggul yaitu melalui:

a) Penyiapan sumber daya manusia (human capital), sesuai dengan keperluan pengem-bangan ekonomi di kawasan, yang banyak sekali kualifikasi dan kebutuhan manusianya, perlu ditangani secara serius;

b) Perlu dilakukan sinergi antara perguruan tinggi serta lembaga pelatihan vokasional, agar aspek yang dihasilkan oleh lembaga pendidikan benarbenar sesuai dengan yang diperlukan oleh pasar tenaga kerja. Hal ini akan mengurangi angka pengangguran, karena begitu lulus dari perguruan tinggi langsung diserap oleh pasar;

c) Perguruan tinggi bisa menjadi pusat dan sekaligus penggerak inovasi dan aplikasi teknologi, serta sekaligus entrepreneurship dan technopreneurship. Perguruan tinggi bisa berinisiatif untuk mendorong kewirausahaan para mahasiwa, bekerja sama dengan pihak ketiga, atau juga perusahaan milik negara, untuk mendorong mereka berani merintis usaha baru.

d) Sektor pendidikan, khususnya perguruan tinggi sendiri, harus pula meningkatkan kesiapan dan daya saingnya karena akan ada kompetisi

4Tilaar, (2003), Kekuasaan dan Pendidikan: Suatu Tinjauan dari Prespektif Studi Kultural, Magelang: Indonesiatera, 2003), hal, 279.

${ }^{5}$ Abudin Nata, Manajemen Pendidikan, hal. 171.

RI'AYAH, Vol. 01, No. 01 Januari-Juni 2016 
dengan negara-negara ASEAN yang lain. Ingat, pendidikan-pun sebagai sektor jasa harus benar-benar berkualitas dan berdaya saing. ${ }^{6}$

Berdasarkan peran strategis PT, termasuk PTKI di era persaingan bebas di atas maka PTKI harus pula dinamis dalam mengikuti dan memenuhi tuntutan dewasa ini. Perguruan Tinggi dewasa ini dituntut:

"Selalu siap mengedepankan quality assurance (penjaminan mutu). Dalam banyak literatur manajemen seringkali mutu didefinisikan sebagai “...the extent to which the product meets the demands" (mutu adalah seberapa besar produk bersesuaian dengan tuntutan), bahkan ada juga yang mendefinisikan mutu sebagai "satisfaction of the customer" (mutu diukur dari kepuasan para konsumen) (Venkatraman, 2007); Berbagai definisi tentang mutu tersebut mengindikasikan bahwa esensi mutu adalah tergantung pada customer atau pelanggan bukan pada produser. Oleh karena mutu bergantung pada pelanggan, maka sesuatu yang bermutu, baik produk maupun jasa, harus sesuai dengan kebutuhan dan persyaratan pelanggan yang kemudian diadopsi dalam standar mutu suatu organisasi. Jika kebutuhan pelanggan berubah, maka persyaratan pelanggan juga berubah. Oleh sebab itu, terhadap standar juga harus selalu dilakukan perubahan ke arah yang lebih baik, begitu seterusnya" ${ }^{7}$

Lebih lanjut dijelaskan bahwa di PT ada tujuh Standar Nasional Pendidikan Tinggi (SNPT) yang harus dipenuhi atau dilampaui sebagai komitmen perguruan tinggi dalam menciptakan kapasitas institusi dan keefektifan pendidikan yang dijalankan. SNPT dimaksud meliputi Visi, misi, tujuan dan sasaran, serta strategi pencapaian (Standar 1). Tata pamong, kepemimpinan, sistem pengelolaan, dan penjaminan mutu (standar 2). Mahasiswa dan lulusan (standar 3). Sumber Daya Manusia (standar 4). Kurikulum pembelajaran, dan suasana akademik (standar 5). Pembiayaan, sarana dan prasarana, serta sistem informasi (standar 6). Penelitian, pelayanan/pengabdian kepada masyarakat, dan kerjasama (standar 7). Ketercapaian standar-standar tersebut secara berkala harus selalu menjadi kontrol perguruan tinggi ybs (internally driven ) sebagai bagian dari Sistem Penjaminan Mutu Internal (SPMI), selanjutnya akan divisitasi dan diakreditasi oleh lembaga independen yaitu BAN-PT dalam menjalankan Sistem Penjaminan Mutu Eksternal (SPME). PT harus siap berbenah dalam menyongsong era persaingan bebas dan terbuka, artinya hanya PT yang bermutulah yang memang siap untuk menghasilkan lulusan yang bermutu.

6http://www.fpcindonesia.org/site/web/index.php/publikasi/pidato/item/359-kesiapanindonesia-menghadapi-masyarakat-ekonomi-asean-mea-dan-peran-perguruan-tinggi-kita, diakses tanggal 25 November 2015.

7http://www.fpcindonesia.org/site/web/index.php/publikasi/pidato/item/359-kesiapanindonesia-menghadapi-masyarakat-ekonomi-asean-mea-dan-peran-perguruan-tinggi-kita, diakses tanggal 25 November 2015.

RI'AYAH, Vol. 01, No. 01 Januari-Juni 2016 
Beberapa hal yang harus dipertimbangkan dalam dinamisasi peran strategis PTKI dalam menyongsong era persaiangan bebas, yaitu terletak pada "ketangguhan unsur pimpinan PTKI sebagai lokomotif PTKI" yang diangkat dengan mempertimbangkan aspek kemampuan untuk melaksanakan "pekerjaan (job), tanggung jawab (responsibility), dan peran (role) sebagai pemimpin lembaga pendidikan Islam". 8 Kemampuan-kemampuan tersebut diperoleh melalui jenjang pendidikan formal dan pendidikan dan pelatihan profesional pada bidangnya masing-masing.

Pada sisi lain, pimpinan PTKI harus selektif dalam menjalin kerjasama dengan tokoh-tokoh politik, sosial budaya yaitu dengan menjalin kerjasama dengan para tokoh yang berkriteria "para pemimpin yang memegangi Islam sebagai religinya yaitu mereka yang memahami arti kepemimpinan visioner dalam Islam sekaligus dapat melakukan proses internalisasi dan memadukannya dengan nilai-nilai sosial budaya dan kearifan lokal yang dimiliki masyarakat". ${ }^{9}$

Setiap pimpinan PTKI dituntut untuk memiliki ketajaman visi dan kedalaman nilai serta normatif, sehingga setiap anggota civitas kademika yang dipimpinnya dapat berkesinambungan dalam mengikuti dinamika perubahan zaman. Artinya secara prinsip, peran pemimpin visioner sangat menentukan kesinambungan dan dinamisasi suatu lembaga pendidikan Islam.

Tuntutan kepemimpinan PTKI di lapangan yaitu seorang pemimpin harus menjadi pimpinan yang ideal, yang harus dapat menjabarkan visi dan misi kepemimpinannya ke dalam program kerja yang nyata, rasional dan operasional. Disebutkan bahwa "banyak sekali visi dan misi yang mandul dan tidak menjadikan inspirasinya dalam memimpin. Kondisi ini menghawatirkan karena visinya hanya sebagai simbol semata."10 Oleh karena itu, PTKI perlu menyiapkan diri lebih dini agar tetap survive di kancah kompetensi dengan lembaga-lembaga pendidikan lainnya. Pimpinan PTKI dituntut untuk melakukan pengembangan secara sistematik dan sistemik PTKI, yang seirama aspek ideologis (visi dan misi), kelembagaan dan langkah operasionalnya serta mencerminkan pertumbuhan (growt), perubahan (change) dan pembaharuan (reform).

Pimpinan PTKI dituntut memiliki normatif dan ketajaman visi. Mereka harus mampu mendeskripsikan secara mendasar dan mendalam tentang manusia yang ingin dihasilkan.Para pimpinan lembaga pendidikan Islam dituntut bersikap terbuka dalam mengembangkan pendidikan, dan secara

8Said Aqil Husin al-Munawar, Aktualisasi Nilai-Nilai Qur'an dalam Pendidikan Islam, (Jakarta: LP3N, 1998), hal. 8.

9Suhari Pane, Kepemimpinan visoner: rakyat rindu pimpinan visioner. (http:/ / www.waspada.co.id/index.php?option=com_content\&view=article\&id=12811:rakyat-

rindu-pemimpin-visioner\&catid=25:artikel\&Itemid=rakyat rindu pimpinan visioner, 2011) diunduh 15 Juni 2011

10Sodiqin, A, Kepeminpinan Visioner, (Medik, no. 3 September-Desember, 2009), hal. 26.

RI'AYAH, Vol. 01, No. 01 Januari-Juni 2016 
dinamis mampu merespon berbagai perubahan dan tuntutan masyarakat muslim, sebagaimana ungkapan bahwa "dunia pendidikan mengalami ketidaksepadanan dengan dunia luar terutama industri dan teknogi". ${ }^{11}$

Berdasarkan kerangka inilah, maka faktor kepemimpinan PTKI yang berbasis masyarakat sangat dibutuhkan peran nyatanya, agar visi PTKI dapat diterjemahkan lebih kontekstual, fungsional dan solutif. Pimpinan PTKI dituntut untuk melaksanakan kepemimpinan yang efektif, yang berperan memberikan arahan kepada semua unsur personalia dalam mencapai tujuan penyelenggaraan kelembagaan PTKI secara maksimal.

Pada prinsipnya kepemimpinan visioner merupakan kepemimpinan yang berdasarkan visi, yaitu: "Kemampuan untuk melihat realitas, memberi pemimpin keyakinan diri yang dibutuhkan untuk mencurahkan perhatiannya secara terus-menerus untuk meyakinkan orang lain bahwa visi tersebut akan menjadi kenyataan. Dalam konteks ini, visi merupakan kekuatan dalam (inner force) yang memberikan energi kepada pemimpin untuk bertindak". ${ }^{12} \quad$ Pada konteks PTKI yaitu kekuatan dari dalam (inner force) yang memberikan energi kepada pemimpin untuk bertindak dalam mengemban amanah visi dan misi PTKI yang menjadi tanggungjawabnya. Di sini nilai-nilai adalah dimensi kritis dan efektifitas kepemimpinan karena merupakan dasar untuk meyakinkan seluruh personalia PTKI dalam segala kebijakan-kebijakan kepemimpinan yang diambilnya.

\section{Arti Kepemimpinan Visioner}

Visi adalah suatu gambaran mental yang jelas mengenai masa depan yang lebih baik yang dikaruniakan kepada orang tertentu karena pemahamannya yang akurat terhadap arti dan makna kehidupan, citra dan pesan diri serta kepekaan terhadap situasi yang ada. Visi dan misi seharusnya mampu menjadi "sumber inspirasi, inovasi, kreatifitas, dedikasi, produktifitas bagi para pemimpin dan setiap orang. ${ }^{13}$ Kepemimpinan visioner yaitu kepemimpinan yang berdasarkan visi. Kemampuan untuk melihat realitas, memberi pemimpin keyakinan diri yang dibutuhkan untuk mencurahkan perhatiannya secara terusmenerus untuk meyakinkan orang lain bahwa visi tersebut akan menjadi kenyataan.

11Malik Fajar, Visi pembaharuan, hal. 91-92.

${ }_{12}^{12}$ Hendro Kusnoto, The Best Manajement Practice, (Jakarta: PT Gramedia, 2001), hal. 41.

13Suhari Pane, Kepemimpinan visoner: rakyat rindu pimpinan visioner. (http://www.waspada.co.id/index.php?option=com_content\&view=article\&id=12811:rakyatrindu-pemimpin-visioner\&catid=25:artikel\&Itemid=rakyat rindu pimpinan visioner, 2011). diunduh 15 Juni 2011

RI'AYAH, Vol. 01, No. 01 Januari-Juni 2016 
Visi merupakan kekuatan dalam (inner force) yang memberikan energi kepada pemimpin untuk bertindak. ${ }^{14}$ Pengembangan organisasi dipengaruhi oleh komitmen akan nilai-nilai yang melatar belakanginya. Pemimpin merupakan orang yang paling ahli dalam mempromosikan dan melindungi nilai-nilai tersebut. Pemimpin yang berhasil adalah mereka yang mampu mempersonifikasikan nilai-nilai yang dianutnya serta menghidupkannya dalam organisasinya. ${ }^{15}$

Kepemimpinan yang baik ialah ketika pemimpin itu mampu: (1) menggerakkan orang pada satu arah yang benar-benar merupakan minat jangka panjang mereka, (2) tidak menyia-nyiakan sumber daya yang langka, (3) tidak membangun sisi gelap keberadaan mereka sebagai manusia. Pemimpin harus memahami bahwa kepemimpinan merupakan pengembangan visi dan strategi, maka perlu orang-orang yang relevan di belakang strategi-strategi ini, serta secara intensif dilaksanakan pemberdayaan SDM organisai untuk membuat visi ini berhasil secara maksimal. 16

Lebih lanjut ${ }^{17}$ dijelaskan bahwa suatu gaya kepemimpinan yang dijalankan seorang pemimpin harus berdasarkan pada visi organisasi berbasis nilai yang diciptakan dan diyakini oleh anggotanya. Kepemimpinan efektif akan tercapai jika memperhatikan 2 yaitu: 1) membuat agenda untuk perubahan yang mencakup: (a) suatu visi yang dapat dan seharusnya menjadi seperti apa bentuk organisasi tersebut; (b) suatu visi yang memperhitungkan minat jangka panjang; (c) strategi untuk mencapai visi, dan (d) strategi yang memperhitungkan semua kekuatan organisasi dan lingkungan yang relevan, dan 2) membangun jaringan pelaksanaan yang kuat, meliputi: (a) hubungan yang mendukung dengan sumber kekuatan utama yang diperlukan untuk melaksanakan strategi; (b) hubungan yang cukup kuat untuk mendatangkan kerjasama, kerelaan, dan kerjasama tim, (c) kelompok inti yang bermotivasi tinggi, dan (d) suatu kelompok inti yang membuat visi ini menjadi kenyataan.

Disebutkan bahwa'18: 1) kepemimpinan yang visioner membutuhkan empat keseimbangan: (a) mampu berhubungan secara terampil dengan para staf dan karyawan (dalam organisasi) yang mengharapkan bimbingan, dorongan dan motivasi; b) mampu memanfaatkan lingkungan eksternal secara maksimal dan berhubungan secara terampil dengan pihak-pihak di luar organisasi yang mempengaruhi keberhasilan organisasi; c) mampu membentuk dan

14Kusnoto, H, The Best Manajement Practice, Jakarta: PT Gramedia, 2001), hal. 41.

15Ibid, hal. 39-40.

16Kotter, J. P, The Leadership Factor (terjemahan: Hari Suminto), Jakarta: PT Premlindo, 1997), hal. 16-17.

17Ibid, hal. 20.

${ }^{18}$ Burt Nanus, Visionary Leadership: Creating a Compelling Sense of Direction for Your Organization. (San Francisco, CA: Jossey-Bass Publishers, 1992), hal. 23.

RI'AYAH, Vol. 01, No. 01 Januari-Juni 2016 
mempengaruhi semua aspek operasi organisasi termasuk pencapaian visi, kualitas sistem pengendalian, struktur organisasi, dan sistem informasi; d) mampu dan cerdik dalam menyiasati masa depan, yakni memperkirakan dan menyiapkan diri atas perubahan yang terjadi akibat globalisasi, reformasi dan pelaksanaan pemerintahan terhadap organisasi yang dipimpinnya dimasa depan; 2) kepemimpinan visioner mampu menghubungkan visi orang-orang lain (karyawan) melalui cara-cara persuasif yang dapat mempengaruhi mereka untuk mengubah persepsi mereka tentang apa yang penting bagi mereka dan bagi organisasi; 3) Kepemimpinan visoner memiliki keahlian dan otoritas untuk mengendalikan perubahan baik secara langsung maupun tidak langsung; 4) kepemimpinan visioner menjalin hubungan yang komunikatif dengan bawahan serta meyakinkan bawahan bahwa kepentingan mereka menjadi bagian dari visi organisasi serta memiliki andil untuk mengimplementasikannya, 5) kepemimpinan visioner selalu menunjukkan inisiatif dan kemauan besar mewujudkan visi. Mereka digerakkan oleh orientasi kepada prestasi dan memiliki ambisi, energi, ketekunan serta sikap pro aktif dalam kadar yang tinggi, 6) kepemimpinan visioner tidak melihat kekuasaan sebagai hal statis yang harus dipertahankan melainkan sesuatu yang bisa diciptakan dan didistribusikan kepada bawahan tanpa mengurangi kekuasaannya sendiri, 7) kepemimpinan visioner mampu: (a) membangun kepercayaan diri para bawahannya, (b) mengkomunikasikan suatu keyakinan akan kemampuan mereka untuk sukses, (c) memberikan atau mendelegasikan wewenang; (d) menciptakan tantangan; (e) mengembangkan akuntabilitas di lingkungan organisas; (f) menerima umpan balik; (g) memberi imbalan terhadap pencapaian visi organisasi.

Berdasarkan penjabaran kepemimpinan visioner yang dikemukakan di atas menunjukkan bahwa untuk mengelola visi dan misi diperlukan kepemimpinan visioner. Kepemimpinan tersebut memiliki sikap, nilai, kemauan, keterampilan dan perilaku organisasi, serta melihat kedepan bagi kemajuan organisasi.

Dijelaskan bahwa ${ }^{19}$ pemimpin visioner yaitu pemimpin yang dapat mentrasformasikan nilai visi yang dimilikinya kepada seluruh anggotanya. Proses transformasi nilai ini dilakukan melalui empat tahap yaitu: a) berbagi visi, dimana para anggota organisasi akan menerima tantangan visi yang jelas, jika visi itu bermakna bagi mereka dan diyakini akan memperbaiki kondisi masyarakat, b) memberdayakan individu, para anggota perlu merasa bahwa mereka berkepentingan dalam terwujudnya visi baru tersebut dan bahwa mereka berpartisipasi dalam merumuskannya, c) pengakuan kerja, suatu visi yang efektif harus menentukan tujuan untuk kinerja yang menantang, tetapi sekaligus menyediakan saluran umpan balik yang aktual, obyektif dan tepat waktu, d) menghargai kinerja, suatu visi yang efektif menghargai kinerja yang

19Siagian, S. P, Teori Pengembangan Organisasi. (Jakarta: Bumi Aksara. 1998), hal.22.

RI'AYAH, Vol. 01, No. 01 Januari-Juni 2016 
memuaskan dan penghargaan dimaksud mencakup pula dukungan manajemen kepada para bawahannya mengambil resiko, memberikan kebebasan bertindak meskipun tindakan itu mungkin berakibat pada kesalahan dan menyediakan informasi guna mendukung pengambilan keputusan hingga pada tingkat yang paling bawah.

Pemimpin visioner dalam proses pengorganisasian anggotanya harus mampu menjalin harmonisasi dan komunikasi untuk menggalang komitmen organisasi, sebab visi organisasi hanya akan berhasil jika semua anggotanya memiliki komitmen yang kuat dalam mewujudkan komitmen organisasi yang telah disepakati.

Pemimpin visioner secara efektif harus mampu mentransformasikan berbagai perubahan rasional dalam organisasinya. Pemimpin visioner dapat menunjukkan karakteristik pemimpin yang transformis. Ada 4 ciri pemimpin yang transformis yaitu: a) memberikan stimulant ketertarikan pada kolega dan bawahan untuk melihat kinerja mereka dari perspektif baru, b) membangun kesadaran terhadap misi dan visi organisasi, c) mengembangkan kemampuan kolega dan bawahan pada tingkat yang lebih tinggi, dan d) memberikan motivasi pada para kolega dan anggota untuk memperhatikan dampak hasil kerja mereka terhadap keuntungan yang didapat oleh kelompoknya. ${ }^{20}$

Pemimpin visioner yang berkarakteristik transformis, yaitu: ${ }^{21}$ a) pemimpin yang memiliki wawasan jauh ke depan dan berupaya memperbaiki dan mengembangkan organisasi bukan untuk saat ini tetapi di masa datang, b) pemimpin sebagai agen perubahan dan bertindak sebagai katalisator, yaitu yang memberi peran mengubah sistem ke arah yang lebih baik, berusaha memberikan reaksi yang menimbulkan semangat dan daya kerja cepat semaksimal mungkin, selalu tampil sebagai pelopor dan pembawa perubahan.

Berdasarkan uraian di atas maka dapat dijelaskan bahwa seorang pemimpin visioner yang berkarakteristik transformis yaitu mempunyai tujuan dan visi misi yang jelas, serta memiliki gambaran yang menyeluruh terhadap organisasinya di masa depan. Pemimpin dalam hal ini berani mengambil langkah-langkah yang tegas tetapi tetap mengacu pada tujuan yang telah ditentukan guna keberhasilan organisasinya. Hubungan kerjasama dan komunikasi dengan bawahan selalu diperhatikan, memperhatikan perbedaan individual bawahan mengenai pelaksanaan kerja maupun kreatifitas kerja masing-masing bawahan dalam mencapai produktivitas tertentu. Pemimpin berani mengambil kebijakan yang berhubungan dengan peningkatan motivasi bawahan dengan pemberian imbalan dan penghargaan sesuai dengan taraf

20Mariane \& Bush, Leadership and Strategic, (London: Sage Publication, 2000), hal. 23.

${ }^{21}$ Komariah, A \& Triatna, C, Visionary Leadership; Menuju Sekolah Efektif. (Jakarta: Bumi Aksara. 2006), hal. 78.

RI'AYAH, Vol. 01, No. 01 Januari-Juni 2016 
kesanggupan bawahan dalam menyelesaikan suatu tugas yang dibebankan kepadanya.

Gaya kepemimpinan transformasional mempunyai karakteristik transparansi dan kerjasama. Ciri dari gaya kepemimpinan transformasional, yaitu: a) adanya kesamaan yang paling utama, yaitu jalannya organisasi tidak digerakkan oleh birokrasi, tetapi oleh kesadaran bersama, b) para pelaku lebih mementingkan kepentingan organisasi daripada kepentingan pribadi, dan (c) adanya partisipasi aktif dari para pengikut atau orang yang dipimpinnya. ${ }^{22}$

Kepemimpinan transformasional dalam hal perilaku pemimpin, memiliki satu atau lebih perilaku berikut ini:

1. Pengaruh yang ideal: pemimpin bersikap sebagai role model dan dikagumi, dihormati, dan dipercaya. Cara yang dilakukan pemimpin melakukan ini adalah dengan mempertimbangkan kebutuhan orang lain di atas kepentingan diri sendiri, berbagi resiko dengan bawahannya, konsisten, dan bertindak sesuai nilai dan moral.

2. Motivasi inspirasional: pemimpin memotivasi dan menginspirasi dengan memberikan makna dan menantang bawahannya untuk bekerja lebih baik dan semangat tim nya meningkat. Perilaku pemimpin yang sesuai dengan ini adalah dengan melibatkan orang lain dalam kegiatan yang berlandaskan visi, menyampaikan harapan dengan jelas, dan bersikap penuh komitmen pada tujuan dan visi.

3. Stimulasi intelektual: pemimpin menstimulasi orang lain untuk lebih inovatif dan kreatif. Pemimpin mendukung inovasi dan kreatifitas dengan cara menerima ide-ide baru dari orang lain, tidak membeberkan kesalahn orang lain secara umum, dan mendorong orang lain untuk mencoba pendekatan yang lain

4. Pertimbangan individu: pemimpin transformasional mempertimbangkan kebutuhan individu untuk berprestasi dan tumbuh dengan bertindak sebagai mentor atau pelatih. Perilaku kepemimpinan yang mempertimbangkan masing-masing individu meliputi menerima perbedaan indivisu dan mensupervisi sesuai dengan kebutuhan individu, mendorong terjadinya komunikasi 2 arah, mendengarkan, dan mendelegasikan. ${ }^{23}$

Pimpinan PTKI perlu mengadopsi gaya kepemimpinan transformasional, agar semua potensi yang ada di PTKI dapat berfungsi secara optimal. Kepemimpinan transformasional dapat didefinisikan sebagai gaya “kepemimpinan yang mengutamakan pemberian kesempatan, dan mendorong semua unsur yang ada dalam sekolah untuk bekerja atas dasar sistem nilai (value

22Bustari, Kepemimpinan Transformasional, (http://eprints.uny.ac id/2916/1/5. 2011), diunduh 15 Juni 2011.

23 Ibid, hal. 35 .

RI'AYAH, Vol. 01, No. 01 Januari-Juni 2016 
system) yang luhur, sehingga semua unsur civitas akademika bersedia, tanpa paksaan, berpartisipasi secara optimal dalam mencapai tujuan ideal PT". ${ }^{24}$

Pada hakekatnya efektivitas PTKI terdiri dari dimensi manajemen dan kepemimpinan, proses manejemen yang menghasilkan aturan-aturan penyelenggaraan, pengelolaan kelembagaan, pengelolaan program, pengkoordinasian kegiatan, monitoring, dan evaluasi sedangkan proses kepemimpinan yang menghasilkan keputusan keputusan kelembagaan, pemotivasian staf, dan penyebaran inovasi.

\section{Kepemimpinan Visioner dalam Islam}

Menurut Islam semua orang adalah pemimpin dan selalu ditekankan untuk amanat terhadap apa yang dipimpinnya dan semua pemimpin akan dituntut pertanggungjawabannya dihadapan Alloh SWT. Beberapa nilai-nilai kepemimpinan dalam Islam yang perlu diperhatikan yaitu: (a) Pemimpin muslim visioner harus mengetahui pentingnya peran seorang pemimpin dalam suatu organisasi (QS. An.am, 165; Al Anbiya, 72-73, Al Baqarah: 124); (b) mencontoh dan menginternalisasikan nilai-nilai kepemimpinan Nabi Muhammad SAW dalam proses berorganisasinya; (c) menunjukkan prinsip amar ma'ruf nahi mungkar (QS Ali Imran, 104); (d), Memahami dan melaksanakan kewajiban untuk menegakkan kebenaran (QS, Al Isra' (81), QS Ali Imran: 60); (e). Melaksanakan amanah kepemimpinan secara baik (QS. An Nisa': 58); (f) Menegakkan keadilan (QS. An Nisa, 58); (g) Menunjukkan kualitas kepemimpinan ideal dan menjadi tauladan bagi seluruh anggotanya.

\section{Kepemimpinan Visioner dan Aplikasinya dalam Kepemimpinan PTKI}

Kepemimpinan merupakan faktor penggerak organisasi melalui penanganan perubahan dan manajemen yang dilakukannya sehingga keberadaan pemimpin bukan hanya sebagai simbol yang ada atau tidaknya tidak menjadi masalah tetapi keberadaannya memberi dampak positif bagi perkembangan organisasi.25 Unsur pimpinan PTKI yang visioner harus dapat eksis memainkan peranannya sebagai seorang pemimpin dan penggerak organisasi melalui penanganan perubahan dan manajemen organisasi yang baik.

Peran seorang pemimpin digambarkan sebagai interaksi sosial yang bermain sesuai dengan hal-hal yang ditetapkan oleh budaya. Sesuai dengan teori peran, harapan-harapan peran merupakan pemahaman bersama yang menuntun seseorang untuk berperilaku dalam kehidupan sehari-hari sesuai dengan kondisi

${ }^{24}$ Agus Sujito, Kepemimpinan pada Sekolah Berstandar Internasional, Varia Pendidikan, Vol. 22, No. 1, Juni 2010, hal. 49-64.

25 Ibid, hal. 40.

RI'AYAH, Vol. 01, No. 01 Januari-Juni 2016 
sosial budaya yang dimiliki. ${ }^{26}$ Maka unsur pimpinan PTKI yang visioner harus mampu menunjukkan perilaku dalam kehidupan sehari-hari sesuai dengan kondisi sosial budaya yang ada di lingkungan lembaga pendidikan, bahkan jika memungkin menjadi pemimpin sosial bagi yang punya peranan penting dalam kehidupan masyarakat, dan sekaligus menjadi model, tauladan dan panutan bagi masyarakat serta ikut aktif dalam penentuan kebijakan-kebijakan sosial yang berimplikasi positif bagi pengembangan kelembagaan pendidikan yang dikelolanya.

\section{Pimpinan PTKI Visioner dan Total Quality}

Secara operasional penerapan kepemimpinan visioner di PTKI yaitu dengan menciptakan budaya mutu di PTKI, dengan mewujudkan 5 hal yaitu:

1. Struktur, yaitu susunan kepengurusan yang diproporsikan sesuai dengan disiplin keilmuannya.

2. Fokus, bahwa keberadaan organisasi tersebut telah diakui secara tegas baik secara hukum ataupun memiliki nilai plus di mata masyarakat, hal ini terkait dengan nilai balik dari masyarakat yang akan memberikan kepercayaan dan minat untuk memakai produk yang dipasarkan.

3. Komunikasi, yaitu sebuah interaksi harmonis yang dilakukan baik secara internal organisasi (setiap orang yang terlibat dalam organisasi ataupun eksternal (masyarakat sebagai konsumsi). Dalam hal ini pembagian tugas sering dijumpai, bahwa yang mengerjakan tugas-tugas hanya orang-orang tertentu (single aktor), hal ini mungkin disebabkan komunikasi yang terputus serta ketidak tegasan pengelola dalam menegakkan kedisiplinan.

4. Gaya (style), yaitu sebuah organisasi yang berjalan di atas nilai-nilai dan tidak bersifat pragmatis. PTKI yang menjalankan pendidikan di tingkatan praktis haruslah mengindahkan nilai-nilai yang berlaku di lingkungan sosialnya, kemudian menjadikannya rujukan dalam menformulasikan draf kerja yaitu kurikulum yang menpresentasikan kepentingan semua pihak (steak holder).

5. Responsif, artinya keterbukaan dalam menerima berbagai saran atau kritik yang konstruktif. Hal ini dappat dijadikan bahan evaluasi terhadap berbagai macam aktivitas kerja yang telah dilakukan sebelumnya, dengan harapan pada waktu selanjutnya dapat lebih optimal dalam bekerja. ${ }^{27}$

Dalam perkembangannya, budaya budaya mutu di PTKI akan di pengaruhi oleh isu-isu kekinian yang terus berlangsung setiap harinya. Terkait dengan permasalahan penciptaan budaya mutu di PTKI, setidaknya terdapat 8 faktor yang mempengaruhi prosesi pengembangan budaya mutu di PT yaitu:

26Ritzer, G. \& Goodman, D.J, Modern Sociological Theory, 6th Edition. Jakarta: Prenada Media Group, 2003), hal. 117.

27 Johns West dan Burham, Managing Quality in School, (London: Prentice Hel, 1988), hal. 99.

RI'AYAH, Vol. 01, No. 01 Januari-Juni 2016 
1. Nilai-nilai dan tugas, yang termasuk di dalamnya masyarakat (publik), unsurunsur yang terdapat dalam lingkungan sosial, mengerti akan hal-hal yang diperbuat. Roda lembaga pendidikan disesuaikan yang dikeluarkan oleh kebijakan pemerintah,

2. Struktur organisasi, artinya bahwa struktur organisasi tersusun secara herarki dengan berbagai macam komponen yang melengkapinya dan dapat dipertanggung jawabkan keberadaannya,

3. Komunikasi, interaksi harmonis yang harus diciptakan di antara kelompokkelompok kerja atau unsur antar individu dalam sharing informasi yang berkualitas,

4. Pengambilan keputusan yang didasari mupakat, dalam artian bahwa keputusan tersebut merupakan representasi dari aspirasi semua pihak dalam rangka peningkatan kualitas,

5. Tempat kerja haruslah nyaman dan dapat memberi suasana fresh yang tentunya diharapkan dapat menimbulkan gairah kerja yang optimal,

6. Rekrutmen dan seleksi, yaitu memilih dan memilah secara slektif dalam menempatkan setiap individu dalam menangani bidang kerja yang telah diatur (job discription),

7. Perencanaan kurikulum yang dinamis, mudah dipahami dan fleksibel,

8. Pengelolaan pendanaan dan sumber dana secara profesional dan tepat guna,

9. Perhatikan terhadap kesejahteraan dan kedisiplinan secara efektif dalam berbagai hal yang terkait,

10.Komunitas, yakni hubungan berkualitas yang dibangun atas dasar kerjasama yang harmonis dan secara kebersamaan terhadap semua relasi kerja dan juga internal lembaga pendidikan. ${ }^{28}$

Pada aktualisasi budaya mutu di lembaga PTKI yang digawangi oleh Pusat Penjaminan Mutu (P2M) PTKI inilah secara spesifik dapat ditemukan implementasi prinsip-prinsip kepemimpinan visoner. Di samping itu juga dapat terlihat pada karakteristik pemimpin visioner yang melakukan proses transformasi visi kepemimpinannya kepada seluruh anggota lembaga pendidikan, penciptaan komunikasi yang harmonis serta gaya yang diterapkannya adalah gaya kepemimpinan transformatif.

\section{Kesimpulan}

Setiap unsur pimpinan PTKI dituntut untuk memiliki ketajaman visi dan kedalaman nilai serta normatif, sehingga setiap anggota civitas akademika yang dipimpinnya dapat berkesinambungan dalam mengikuti dinamika perubahan zaman. Artinya secara prinsip, peran pemimpin visioner sangat menentukan kesinambungan dan dinamisasi PTKI.

28 Ibid, hal. 100-101.

RI'AYAH, Vol. 01, No. 01 Januari-Juni 2016 
Tuntutan kepemimpinan PTKI di lapangan yaitu seorang pemimpin harus menjadi pimpinan yang ideal, yang harus dapat menjabarkan visi dan misi kepemimpinannya ke dalam program kerja yang nyata, rasional dan operasional. Terdapat lima hal perwujudan dari budaya mutu PTKI yaitu: struktur, fokus, atau legalitasnya diakui, komunikasi, gaya (style) yang dinamis, dan responsif. Terdapat hal-hal yang mempengaruhi pelaksanaan perwujudan budaya mutu di PTKI dan terdapat pula hal-hal yang harus diperhatikan oleh unsur pimpinan PTKI dalam prosesi pencapaian total quality.

Secara operasional penerapan kepemimpinan visioner di PTKI yaitu dengan menciptakan budaya mutu dan total quality di PT. Pada orientasi dan aktualisasi budaya mutu yang digawangi oleh P2M inilah secara spesifik dapat ditemukan dari penerapan prinsip-prinsip kepemimpinan visioner di PTKI.

\section{Daftar Pustaka}

Abudin Nata, Manajemen Pendidikan: Mengatasi Kelemahan Pendidikan Islam di Indonesia, Jakarta: Prenada Media, 2003.

Agus Sujito, Kepemimpinan pada Sekolah Berstandar Internasional, Varia Pendidikan, Vol. 22, No. 1, Juni 2010, 49-64.

Bass, B.M., \& Avolio, B.J, Improving organizational affectiveness through transformational leadership. Thousand Oaks, CA : Sage, 1994.

Burt Nanus, Visionary Leadership: Creating a Compelling Sense of Direction for Your Organization, San Francisco, CA: Jossey-Bass Publishers, 1992.

Bustari, Kepemimpinan Transformasional, (http://eprints.uny.ac id/2916/1/5. 2011), diunduh 15 Juni 2011.

Hasymi Ali, Organisasi dan Manajemen 2. Jakarta: Bumi Aksara, 2007.

Hendro Kusnoto, The Best Manajement Practice, Jakarta: PT Gramedia, 2001.

http://www.fpcindonesia.org/site/web/index.php/publikasi/pidato/item/359

-kesiapan-indonesia-menghadapi-masyarakat-ekonomi-asean-mea-danperan-perguruan-tinggi-kita, Diambil 25 November 2015.

http:/ / stkipbima.ac.id/profesi-guru-di-antara-peluang-dan-tantangan-dalamera-masyarakat-ekonomi-asean-mea-2015/, Diambil 25 November 2015

Johns West dan Burham, Managing Quality in School, London: Prentice Hel, 1988.

Komariah, A \& Triatna, C, Visionary Leadership; Menuju Sekolah Efektif. Jakarta: Bumi Aksara. 2006.

Kotter, J. P, The Leadership Factor (terjemahan: Hari Suminto), Jakarta: PT Premlindo, 1997.

Kusnoto, H, The Best Manajement Practice, Jakarta: PT Gramedia, 2001.

Malik Fajar, Visi Pembaharuan Pendidikan Islam, Jakarta: LP3N, 1998.

Mariane, C \& Bush, T, Leadership and Strategic. London: Sage Publication, 2000.

Ritzer, G. \& Goodman, D.J, Modern Sociological Theory, 6th Edition. Jakarta: Prenada Media Group, 2003), h. 117.

Said Aqil Husin al-Munawar, Aktualisasi Nilai-Nilai Qur'an dalam Pendidikan Islam, Jakarta: LP3N, 1998.

Siagian, S. P, Teori Pengembangan Organisasi. Jakarta: Bumi Aksara. 1998.

RI’AYAH, Vol. 01, No. 01 Januari-Juni 2016 
Sodiqin, A, Kepeminpinan Visioner, Medik, no. 3 September-Desember, 2009.

Sudrajat, A, Kepemimpinan dan masalah Legitimasi dalam Perspektif Islam, artikel. http://www.google.co.id/\#q=kepemimpinan+dalam+islam.pdf\&hl=id\& prmd=ivns\&ei=AAH4TfeRBI6evgP0womDDA\&start=10\&sa $=$ N\&fp=3eb2

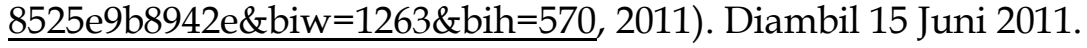

Suhari Pane, Kepemimpinan visoner: rakyat rindu pimpinan visioner. (http:/ / www.waspada.co.id/index.php?option=com_content\&view=arti cle\&id=12811:rakyat-rindu-pemimpinvisioner\&catid=25:artikel\&Itemid=rakyat rindu pimpinan visioner, 2011) diunduh 15 Juni 2011.

Tilaar, Perubahan Sosial dan Pendidikan: Pengantar Pedagogik untuk Indonesia, Jakarta: PT Grasindo, 2002.

Tilaar, Kekuasaan dan Pendidikan: Suatu Tinjauan dari Prespektif Studi Kultural, Magelang: Indonesiatera, 2003.

Undang-Undang Sisdiknas No. 20. Tahun 2003, pasal 3. 